\title{
分子ディスプレイとコンビバイオによる創薬への挑戦
}

芝崎誠司, ${ }^{*}, a$ 植田充美 $b$

\section{Facing Challenges for Drug Discovery Using Molecular Display Technology and Combinatorial Bioengineering}

\author{
Seiji SHIBASAKI ${ }^{*, a}$ and Mitsuyoshi UedA ${ }^{b}$ \\ ${ }^{a}$ Department of Pharmacy, School of Pharmacy, Hyogo University of Health Sciences, 1-3-6 Minatojima, \\ Chuo-ku, Kobe 650-8530, Japan, and ${ }^{b}$ Division of Applied Life Sciences, Graduate School of \\ Agriculture, Kyoto University, Kitashirakawa-oiwake-cho, Sakyo-ku, Kyoto 606-8502, Japan
}

細胞の最外殼層には，細胞膜あるいは細胞壁が存 在し，細胞外部との境界としての役割を果たしてい る.これらの境界は，細胞内部と外部を隔てている 単なる仕切りとしてではなく，レセプターや細胞間 接着に係わるタンパク質分子に代表されるように, 細胞同士がコミュニケーションを行う場となってお り，様々な生物のゲノムが解明されるなか，今なお 数多くの謎に包まれた細胞内の遺伝子情報を具現化 し，分子情報として外界に発信する魅力的な領域と して機能している.

本来, 生理機能を維持するために, 細胞表層でそ れぞれの役割を担っているタンパク質の分子情報を 活用し, 分子生物学的手法により外来タンパク質, ペプチドを表層に提示する，分子ディスプレイ技術 が開発されてきた. ${ }^{1,2)}$ ファージのコートタンパク質 に目的タンパク質を融合させてディスプレイする, いわゆるファージディスプレイは，1985 年に Smith らが最初に提案した分子ディスプレイ技術で あり，遺伝子ライブラリーを組込んだファージミド を導入することで，組換えファージ集団から望む性 質を持つクローンを取得する手法が確立され，今日 に至っている. 1990 年代以降, ファージを含め, バクテリア，酵母などの微生物細胞，あるいは無細 胞抽出系におけるリボソームなどを用いた分子ディ スプレイ法が, 同様のコンセプトのもと発展してい

$a$ 兵庫医療大学薬学部医療薬学科（干650-8530 神戸市 中央区港島 1-3-6), $b$ 京都大学大学院農学研究科応用 生命科学専攻（干606-8502 京都市左京区北白川追分町） *e-mail: seiji@huhs.ac.jp

日本薬学会第 129 年会シンポジウム S05 序文
る。これらを用いた研究により，分子生物学や細胞 生物学分野において新たなる知見が得られ，医薬と して期待できる分子の探索に有用であることが数多 く報告されている. ${ }^{3)}$

さらにポストゲノム時代を迎えた今，これらの分 子ディスプレイ法に加え，ハイスループット探索法 を駆使した「コンビナトリアル・バイオエンジニア リング (以下，コンビバイオ)」という新しい分子 や細胞の創製技術 ${ }^{4}$ について, 薬学を始め, 関連分 野においても期待が集まっている。コンビバイオ は，有機合成化学的手法を駆使した，いわゆるコン ビナトリアル・ケミストリーとは異なり, 生細胞や 酵素を分子ツールとし，細胞が持つ自己増殖能を利 用した新しい分子創製方法である。多様性を生み出 すコンビバイオ技術を分子ディスプレイに応用した 一例としては，黄色ブドウ球菌由来 Protein A の Z ドメインの人工抗体化が成功を収めている. ${ }^{3,5)} し か$ し，ファージの系ではパンニング等の煩雑な操作が 必要であるという久点も残されている，自己増殖で き，かつ扱いが容易な細胞を用いた系はこれらの問 題解決に有効であり, タンパク質の発現系としてい くつかの系を用意することでお互いを補完できるこ とも多い.この場合だと大腸菌や酵母の分子ディス プレイ系(6)が非常に強力なツールとして利用できる.

今日, 次世代シークエンサーや, 各種アレイ, セ ルソーターなどの解析用最先端ハードが続々と開発 され，大量生命情報の高速処理技術の発展は目覚ま しいものがある. しかし，その対象はあくまでも生 命の中心である細胞とその構成分子群であり，こう した機器類の進歩に呼応すべく，細胞ならびに分子 
の創製技術も常に進化し続ける必要がある。また， 遺伝子，タンパク質分子に関する大量の情報が容易 に入手できる現在，それらのデータベースを最大限 に活用し，生理活性を有する人工分子の創出のため の様々な方法論のなかでも，分子ディスプレイやコ ンビバイオ技術は有力な選択肢として今後期待され るところが大きい.

本誌上シンポジウムでは, 129 年会における当該 シンポジウムのオーガナイザーを含む 8 名のすべて のシンポジストが執筆しており，分子ディスプレイ やコンビバイオを創薬研究に生かすための，それぞ れのシンポジストが取組んでいる研究の最前線が網 羅されている，また，魚，酵母，バクテリア，フ アージ，乳酸菌など，多様な生物種において利用で きる技術であることがお分かり頂けるはずである. 新しい分子，細胞創製技術による創薬を目指した取
り組みと，その展望についての議論から，読者ご自 身の研究に役立つような次世代型分子創製ツールを 見い出して頂ければ幸いである.

\section{REFERENCES}

1) Ueda M., Tanaka A., Biotechnol. Adv., 18, 121-140 (2000).

2) Gai S. A., Wittrup K. D., Curr. Opin. Struct. Biol., 17, 467-473 (2007).

3) Shibasaki S., Ueda M., Recent Pat. Biotechnol., 3, 19-27 (2009).

4) Ueda M., Kondo A., J. Mol. Catl. B Enzym., 28, 137 (2004).

5) Shibasaki S., Maeda H., Ueda M., Anal. Sci., 25, 41-49 (2009)

6) Shibasaki S., Tanaka A., Ueda M., Biosens. Bioelectron., 19, 123-130 (2003). 